TOKÁR-SZADAI Ágnes

\title{
A VEZETÉSI TANÁCSADÁSI PROJEKTEK ÉRTÉKELÉSE
}

A Miskolci Egyetem Gazdálkodástani Intézete 2001-ben, 2005-06-ban, majd 2011-12-ben kérdốives felmérést végzett tanácsadó cégek, valamint ügyfeleik körében. A tanulmányban a szerzó a vezetési tanácsadók és a tanácsadási projektek értékelési szempontjainak szakirodalmi összefoglalását követóen bemutatja, hogy a vállalkozók mennyire elégedettek az igénybe vett tanácsadási szolgáltatással: hogyan értékelik a különböző́ nagyságú tanácsadó cégek teljesítményét, milyennek látják a tanácsadóval való kapcsolatukat, mennyire elégedettek a tanácsadó szakmai kompetenciájával, milyennek ítélik meg a szolgáltatás ára és a teljesítés színvonala közötti kapcsolatot, véleményük szerint a kapott javaslat mennyire volt megoldásra orientált, és melyek az esetleges elégedetlenségük okai. ${ }^{1}$

Kulcsszavak: vezetési tanácsadó, tanácsadási projekt, értékelési szempontok, megítélés, elégedettség, elégedetlenség okai, kérdő́ives felmérés

A tanácsadási szakma elnevezése a hazai és nemzetközi szakirodalomban nem egységes, számos megközelítési mód és meghatározás létezik (Tokár-Szadai, 2012). Jelen cikkben és az alapjául szolgáló felmérésekben Kubr megközelítését alkalmazom, aki a következő fogalmat használja a tanácsadással kapcsolatban: „A vezetési tanácsadás egy olyan független, szakértôii szolgáltatás, melyet szervezetek és azok vezetối számára nyújtanak abból a célból, hogy segítsék a szervezeteket céljaik elérésében, a problémák feltárásában, megoldásában, új lehetőségek felkutatásában és azok megoldásában, a szükséges tudás elsajátításában és a változások megvalósításában.” (Kubr, 2002: p. 10.)

A FEACO 2000 és 2004 között az 1. táblázatban látható módon határozza meg a vezetési tanácsadási szolgáltatás területeit.

A klasszikus értelemben vett, szigorúan értelmezett vezetési tanácsadás (management consulting) jelentése az elmúlt évtizedekben jelentôsen kibóvült, és a kereslet az újabb területek irányába tolódott el. Így a „management consulting” kifejezés jelentése is változik. A tanácsadási piacon jelenlévő tendenciákat figyelembe véve változtatta meg a FEACO kategóriáit 2005-ben, ezt foglalja össze a 2. táblázat.

Vezetési tanácsadási szolgáltatások

\begin{tabular}{|l|l|}
\hline $\begin{array}{l}\text { Stratégiai tanácsadás } \\
\text { - Stratégiai tervezés } \\
\text { - Szervezetfejlesztés } \\
\text { - Púziók, felvásárlások } \\
\text { - Marketang- és cégkommunikáció } \\
\text { - Pénzügyi tanácsadás }\end{array}$ & $\begin{array}{l}\text { Humáneróforrás-tanácsadás } \\
\text { - Fejvadászat } \\
\text { - Oktatás } \\
\text { - Jövedelem, jutalmazás, juttatások } \\
\text { - Outplacement }\end{array}$ \\
\hline $\begin{array}{l}\text { Múködési (operatív) tanácsadás } \\
\text { - Üzleti folyamatok átszervezése } \\
\text { - Változáskezelés } \\
\text { - Projektvezetés } \\
\text { - Ellátási lánc irányítása }\end{array}$ & $\begin{array}{l}\text { Informatikai tanácsadás } \\
\text { - Általános informatikai tanácsadás }\end{array}$ \\
\hline $\begin{array}{l}\text { Outsourcing } \\
\text { (tevékenység kihelyezése, tevékenység } \\
\text { kiszervezése) }\end{array}$ & \\
\hline
\end{tabular}

Forrás: FEACO (2000-2004) 
A vezetési tanácsadás területei

\begin{tabular}{|c|c|}
\hline Üzleti tanácsadás $\sqsubset$ & Üzleti tanácsadás \\
\hline Informatikai tanácsadás & - Stratégiai tanácsadás \\
\hline Rendszerfejlesztés-integráció & • Mú́ködési (operatív tanácsadás) \\
\hline Outsourcing & - Projektmenedzsment \\
\hline Egyéb szolgáltatások & $\begin{array}{l}\text { - Változásmenedzsment } \\
\text { - HRM-tanácsadás }\end{array}$ \\
\hline
\end{tabular}

Forrás: FEACO (2005-2012)

A korábban egy kategóriaként szereplő informatikai tanácsadást két részre osztották: informatikai tanácsadásra (szervezeteknek segít az IT-stratégia kialakításánál) és rendszerfejlesztés és integrációra (alkalmazások fejlesztése - szoftver és bevezetése).

A korábban önálló stratégiai és múködési tanácsadás az üzleti tanácsadás része lett. A korábban a múködési területen nyilvántartott projekt- és változásmenedzsmentet az üzleti tanácsadáson belül önállóan tartják nyilván.

Az outsourcing (kiszervezés, feladatkihelyezés) a következő három típusú tevékenységet tartalmazza: IT-menedzsment szolgáltatások, alkalmazott menedzsment szolgáltatások (AMS - applied management services), valamint az üzleti folyamatok kiszervezése (BPO - business process outsourcing).

2005-ben megjelent az „egyéb” kategória, a korábbi adatokban ez nem szerepelt külön, az egyes területek részeként tartották nyilván.

Meg kell jegyezni, hogy a kategóriák megváltozásával a 2005 elótti és utáni adatok közvetlenül nem összehasonlíthatók. Egyes kategóriák összevonásával az összehasonlíthatóság elvileg biztosítható, de a gyakorlatban nem teljeskörúen (Tokár-Szadai, 2012). Ebból adódóan, valamint a korábbi felmérésekkel történő összehasonlíthatóság érdekében a felmérésekben a FEACO 2005 előtti kategóriáit alkalmaztam.

A közelmúltban kitudódott hazai tanácsadási botrányok (Pénzes, 2009) (Bódis, 2008) (pl. BKV, DRV Zrt., STRABAG stb.) következtében sokat romlott a tanácsadók megítélése az elmúlt idôszakban, mely fóként a média egyoldalú tájékoztatása miatt hibás általánosításhoz és előítéletekhez vezethet (Tokár-Szadai, 2013a). Az objektív tájékozódás és tájékoztatás érdekében fontosnak tartom a tanácsadási szolgáltatást már igénybe vett vállalkozók tapasztalatainak vizsgálatát: hogyan értékelik a tanácsadójukat (kompetenciáit és a kialakult szakmai kapcsolatot), mennyire elégedettek az igénybe vett szolgáltatás megoldásra orientáltságával és az ár-teljesítmény viszonnyal.

\section{A vezetési tanácsadási projektek értékelésének szempontjai}

A megbízás befejezésének közeledtével jó alkalom nyílik az értékelésre. Bizonyos előnyök már ilyenkor is azonosíthatóak az ügyfél számára, és visszatekintve értékelhetố a tanácsadási folyamat. A megbízást lezáró értékelés minden bizonnyal a legfontosabb, nem szabad azonban, hogy ez legyen az egyetlen. Az értékelésnek a megvalósítás végéig tartó késleltetése azzal járhat, hogy túl késő lesz a megbízásról bármiféle hasznos javaslattal előállni, és ezeknek a javaslatoknak már csak a jövőbeli megbízásoknál vehetjük hasznát. Ezért kell előre gondoskodni a diagnosztikai és a cselekvéstervezeti szakaszok végén esedékes időközi értékelésekról. Ezeket az értékeléseket úgy kell tekinteni, mint a megbízás az ügyfél és a tanácsadó által végzett közös ellenôrzésének és szabályozásának természetes részét.

Annak megállapítása, hogy milyen mértékben valósult meg a kitúzött cél, meglehetôsen bonyolult feladat. Csak nagyon ritkán valósul meg száz százalékban a korábban elképzelt „új helyzet”. A folyamat, az együttmúködés során gyakran merül fel újabb probléma, illetve a kezdeti szakaszban még nem látható egyéb momentum. A tanácsadás végsố célja nem a munkatervben, illetve ajánlatban megfogalmazott célok maradéktalan teljesítése, hanem a vállalkozás összeredményességének, értékének, versenyképességének növelése. A projekt eredményessége a végsố célhoz való hozzájárulással, illetve az ügyfél elégedettségével, nem a megvalósult munkatervi pontok arányával mérhető (Pelczné Gáll Szadai, 2006).

Mielőtt az értékelés módszeréról döntenénk, a következő kérdések végiggondolása, megválaszolása szükséges: Mit kell értékelnünk? Miért? Milyen eredményeket várunk tôle? Hogyan végezzük az értékelést? Rendelkezésre állnak-e az adatforrások? Ki végezze a mérést? Ki szolgáltassa az adatokat? Ki lássa az eredményeket? Mennyibe kerül az értékelés? (Niedereicholz, 2008)

Az értékelés alapvető funkciója annak a kérdésnek a megválaszolása, hogy teljesültek-e a szerződésben foglaltak. A különbözô szakemberek egyetértenek abban, hogy a tanácsadás eredményessége csak részben függ a feladat megoldása során alkalmazott konkrét módszerektől.

Legalább ugyanilyen fontos az eredményesség szempontjából a tanácsadó és ügyfele között kialakult jó együttmúködés (Poór, 2010).

Az ügyfél és a tanácsadó értékelésének egy lehetséges módját mutatja a 3. táblázat (Hoványi, 1997). 
A táblázatban az egyes szempontoknak történő megfelelést 5 fokozatú Likert-skálán értékelik. (1-5-ös minősítéssel felelhet meg az ügyfél, illetve a tanácsadó a vizsgált szempontoknak, ahol az 5-ös a maximális megfelelés.) A súlyozás azt fejezi ki, hogy az adott szempontoknak mekkora volt a jelentôsége a tanácsadás egészében: 10-es maximális jelentőség, 1-es: elhanyagolható. A súlyozott érték a minősítés és a súlyozási érték szorzata. A módszer jelentősége abban áll, hogy felhívja a figyelmet arra, hogy nem elég a projekt végén a tanácsadó értékelése. Az ügyfelek szerepe a feltételek megteremtésében, biztosításában és hozzáállása, együttmúködése a teljes tanácsadási folyamatban nélkülözhetetlen a projekt eredményessége szempontjából. A módszer a tanácsadók és ügyfelek jellemzésének szempontjait azonos részletezettséggel veszi figyelembe, a súlyozás az alkalmazóktól függ.

Kubr (2002) kiemeli, hogy melyek azok a legfontosabb kérdések, melyeket az értékeléskor végig kell gondolni.

\section{A megbízás tervezete (a szerzódés)}

Érdemes a kapcsolat elejének vizsgálatával kezdeni. A felvetendő kérdések a következók:

- Ki és hogyan alapozta meg a tanácsadás szükségességét?

- Hogyan választották ki a tanácsadót? Milyen kritériumokat és eljárásokat használtak? Érthetô volt-e a tanácsadás célja? Túlságosan szúk vagy határozatlan volt-e?

- A megbízás terve világos, élethú és megfelelő volt-e, tekintettel az ügyfél szükségleteire és különleges feltételeire?

- A célok, tárgyak, eredmények és ráfordítások eredeti meghatározása jó keretet és segítséget adott-e a megbízási tervhez? A célok eléggé igényesek, de nem megvalósíthatatlanok voltak-e?
3. táblázat a ,2×12-es módszer"

\begin{tabular}{|l|l|l|l|}
\hline \multicolumn{1}{|c|}{ Az ügyfél jellemzésének szempontjai } & Minósítés & Súlyozás & $\begin{array}{c}\text { Súlyozott } \\
\text { érték }\end{array}$ \\
\hline 1. Problémalátásának helyessége & & & \\
\hline 2. Nyitottsága a problémák megbeszélésére & & & \\
\hline 3. Tárgyalási stílusa & & & \\
\hline 4. Együttmúködése az átvilágítás szakaszában & & & \\
\hline 5. Együttmúköódése a javaslatok kimunkálásában & & & \\
\hline 6. Vezetóinek viszonya a javasolt változtatásokhoz & & & \\
\hline 7. Munkatársak viszonya a javasolt változtatásokhoz & & & \\
\hline 8. Együttmúködése a megvalósítás realizálásában & & & \\
\hline 9. Szerepe a határidók betartásában & & & \\
\hline 10. A tervezett pénzforrások rendelkezésre bocsátása & & & \\
\hline 11. A szerzódésben foglaltak betartása & & & \\
\hline 12. Rugalmassága a tanácsadás során & & & \\
\hline
\end{tabular}

\begin{tabular}{|l|l|l|l|}
\hline \multicolumn{1}{|c|}{ A tanácsadó jellemzésének szempontjai } & Minósítés & Súlyozás & $\begin{array}{c}\text { Súlyozott } \\
\text { érték }\end{array}$ \\
\hline 1. A problémafelismerés helyessége & & & \\
\hline 2. A munkacsoport szakmai összetételének helyessége & & & \\
\hline 3. A döntó tényezók felismerése az átvilágítás során & & & \\
\hline 4. A rendszerben gondolkodás megvalósítása & & & \\
\hline 5. A javaslatok helyessége & & & \\
\hline 6. A prezentálás meggyózó jellege & & & \\
\hline 7. A tervezett ráfordítások helytállósága & & & \\
\hline 8. A tervezett határidók betartása & & & \\
\hline 9. Az ügyféllel kialakított kapcsolat zavartalansága & & & \\
\hline 10. A munkacsoport légköre és kreativitása & & & \\
\hline 11. A munkacsoport-vezetó értékelése & & & \\
\hline 12. A munkacsoport tagjainak egyéni értékelése & & & \\
\hline
\end{tabular}

A várható eredmények meghatározása egyértelmú, alapos és pontos volt-e?

- A tanácsadói stílus megfelelóen meghatározott, megvitatott és érthetố volt-e? Tájékoztatták-e az embereket a szerepükról és kötelezettségeikról?

\section{A ráfordítások mennyisége és minôsége}

A szükséges - megbízási tervben szereplő - ráfordítások eredeti meghatározásán kívül az értékelésben meg kell vizsgálni a ráfordításokat, amelyeket a tanácsadó és az ügyfél biztosított. A fő kérdések:

- A tanácsadó kívánt méretú, szerkezetú és szakértelmú csoportot választott-e?

- Biztosította-e az ügyfél a megbízáshoz szükséges (emberi és egyéb) erőforrásokat? 


\section{Afelhasznált tanácsadói módszer}

A tanácsadónak és az ügyfélnek viszszamenőlegesen értékelnie kell a megtörtént eseményeket, és azokat az összefüggéseket, amelyek a megbízás ideje alatt fennálltak:

- Milyen volt a tanácsadó-ügyfél kapcsolat természete? A kölcsönös bizalom, megértés, tisztelet és támogatás légköre volt jellemzó?

- A megfelelố tanácsadói stílust használták? Az ügyfelek képességeihez és preferenciáihoz, valamint az adott feladathoz igazították-e?

- Minden kedvezó alkalmat kihasználtak-e, hogy növeljék az ügyfél bevonását a megbízásba?

- Megfelelő figyelmet szenteltek-e a megbízás tanulási szakaszainak? Mit tettek, hogy átadják a tudást és a szakértelmet az ügyfélnek?

- Lelkiismeretesen betartotta-e a tanácsadó a szakma minden etikai és viselkedési szabályát?

\section{Irányítása a tanácsadó és az ügyfél által}

Az eredeti megbízási tervben szereplő hiányosságok és hibák korrigálhatók, a megváltozott körülmények által megkívánt módosítások elvégezhetốk, ha a megbízást a partnerek megfelelően irányítják. Értékeléskor a következő kérdéseket célszerú végiggondolni:

- Az eredeti megbízási terv tartalmaz-e rugalmasságot?

- A tanácsadó cég hogyan irányította és támogatta a megbízást? Hogyan reagált az ügyféltől érkezô panaszokra és javaslatokra?

- Hogyan ellenórizte és felügyelte az ügyfél a megbízást?

- Figyelembe vette-e a tanácsadó és az ügyfél a menetrendet?

- Volt-e évközi jelentés és értékelés a megbízás kulcsfontosságú szakaszaiban? Mit tettek ennek érdekében?

Philips (2000) szerint a tanácsadás egy befektetési folyamat, ezért ki kell mutatni az értékelés során, hogy milyen is volt a projekt befektetetteszköz-megtérülési mutatója (ROI: Return on Investment). Így többek között a következó kérdések vizsgálata fontos:

- Milyen volt a tanácsadással közvetlenül kapcsolatban lévốk elégedettsége és reakciói? (Elégedettség, reakció),
1. ábra

-12) tevékenységi kör szerinti összetétele

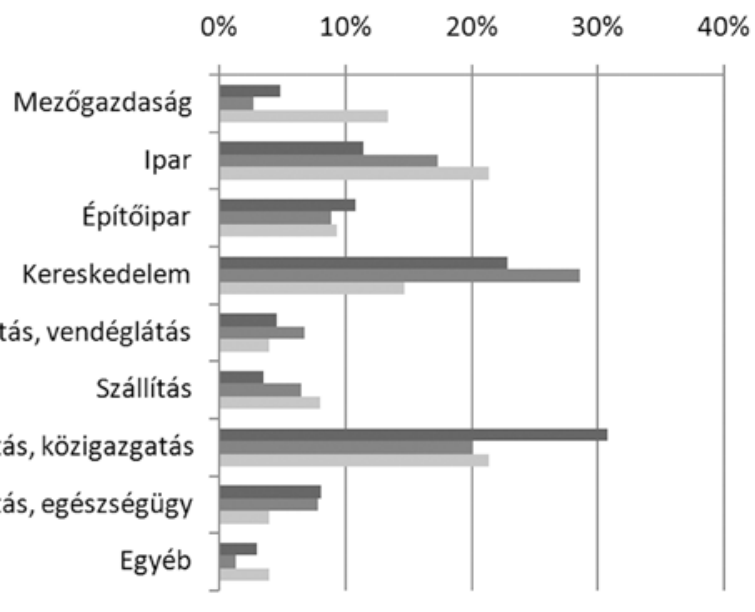

B-A-Z megye, $2005=\operatorname{minta}, 2005=\operatorname{minta}, 2011-12$

- Mit tanult a szervezet a tanácsadás által? (tanulás),

- Milyen eredménnyel lehetett megvalósítani a tanácsadók javaslatát? (implementálás, alkalmazás),

- A javasolt változtatásoknak milyen üzleti kihatásai voltak? (üzleti hatás),

- Milyen üzleti hasznot eredményezett a tanácsadók javaslatainak bevezetése? (költség-haszon elemzés),

- Milyen közvetlenül nem számszerúsíthetố eredményeket hozott a tanácsadók javaslatainak bevezetése? (nem számszerúsíthetố eredmények Intangible benefits) (Poór, 2010).

\section{Az empirikus felmérések módszertani háttere}

Az empirikus vizsgálat alapját jelentô kérdőív a korábbi, külföldi kutatások során alkalmazott kérdôívek figyelembevételével állt össze. A kérdőív szerkesztésénél lényeges szempont volt, hogy egy-egy témát több oldalról is megvilágítsanak a kérdések, növelve ezzel a válaszokból levonható következtetések megbízhatóságát. Az empirikus vizsgálat két részből tevődött össze.

A kutatás kiterjedt egyrészt a Borsod-Abaúj-Zemplén megyei vállalkozások megkérdezésére, a tanácsadási szolgáltatás igénybevételére. A Borsod-Abaúj-Zemplén megyei vállalkozások körében 300 tagú, értékelhetô minta összeállítása volt a cél. Korábbi felméréseink tapasztalatai alapján személyes megkereséssel és rábeszéléssel 50\% körüli visszaérkezési arány érhetô el. Ezért 600 vállalkozást választottunk ki (az összes múködő B-A-Z megyei társas vállalkozás 3,5\%a) a Cégtár 2000/12-es, illetve 2005-ös számaiból (a Cégbíróságon bejegyzett, B-A-Z megyében székhely- 
lyel rendelkező, múködő cégek közül), és személyesen kerestünk fel. A cégek kiválasztása a tevékenységi kör alapján részletezett vállalkozások közül történt, a területi elhelyezkedés arányait figyelembe véve, egyszerú véletlen mintavétellel. Így 2001-ben 362 db, 2005-06ban 294 db értékelhető kérdőívet sikerült kitöltetni. A visszaérkezési arány 2001-ben 60,3\%, 2005-06-ban $49 \%$ volt. A vissza nem érkezett kérdő́ivek miatt- a szolgáltatás egy kicsit alul-, az ipar és kereskedelem egy kicsit felülreprezentált volt 2005-ben, az eltérés nem volt számottevő, jól követte a megyei arányokat (1. ábra).

A kutatás másik része a tanácsadó vállalkozások megkérdezésére épült. 2001-ben és 2005-ben teljes körú felmérést végeztünk a 7.414 „,üzletviteli tanácsadás” TEÁOR számú, Borsod-Abaúj-Zemplén megyei székhelyú tanácsadó cégek körében. 2000 decemberében 199 tanácsadó cég múködött megyénkben, 2005-ben 222, valamennyit felkerestük. A kérdőív kitöltését 2001-ben 83, 200506-ban 88 tanácsadó vállalta. A visszaérkezési arány kisebb volt, mint a vállalkozások körében, 40\% körüli (2001-ben 41,7\%, 2005-06-ban 39,6\%) (Pelczné Szadai, 2003a, b; (Pelczné - Szadai, 2004; Szadai, 2006).

A rendelkezésre álló korábbi kérdőíves felmérések, valamint a saját korábbi kutatási eredmények egy újabb empirikus felmérés alapjául szolgáltak. A kérdő́ivek összeállítására a 2011. szeptember-november közötti idôszakban, az adatfelvételre 2011. december és 2012. május között került sor. A tanácsadói kérdőívet 58 vállalkozás töltötte ki. (Tanácsadónak tekintettük azon vállalkozókat, akik tevékenységeik között megjelölték az „,̈zletviteli tanácsadást”. A tanácsadói kérdő́ivet a tanácsadási tevékenységre vonatkozóan töltötte ki egy tanácsadást folytató kolléga.) A megvizsgált tanácsadók 1-2 ügyfele pedig kitöltötte a „tanácsot igénybe vevő vállalatok tanácsadási tapasztalatára" vonatkozó kérdőívet (77 kitöltött kérdőív érkezett vissza): így összehasonlíthatóvá vált, hogy a tanácsadók hogyan látják saját magukat, kompetenciáikat, tevékenységük eredményét, hogyan látják óket ügyfeleik, vannak-e eltérések, miból adódnak ezek. A szolgáltatást igénybe vett vállalkozók valamennyi iparágat képviseltek. (1.ábra)

A kérdőív úgy került összeállításra, hogy összehasonlítható legyen a korábbi (2001-es és 2005-06-os) felmérések eredményeivel. Az összehasonlíthatóság nem biztosítható teljeskörúen, mivel eltér a felmérés köre: a korábbi felmérések csak Borsod-Abaúj-Zemplén megyére irányultak, a mostaniak több régióra. (2. ábra) A korábbiak két külön részből álltak: a tanácsadókra és a vállalkozásokra. A mostani a tanácsadókra vonatkozik, és a megkérdezettek ügyfeleire. Az összehasonlíthatóság így nem biztosítható teljes mértékben, de a tendenciákra következtetni lehet (Tokár-Szadai, 2013 b).

A 3. ábra a 2011-12-ben igénybe vett tanácsadási szolgáltatások területenkénti megoszlását szemlélteti.

2. ábra

A vizsgált tanácsadók és ügyfeleik székhely szerinti megoszlása, 2011-2012

$0 \% \quad 10 \% \quad 20 \% \quad 30 \% \quad 40 \% \quad 50 \%$

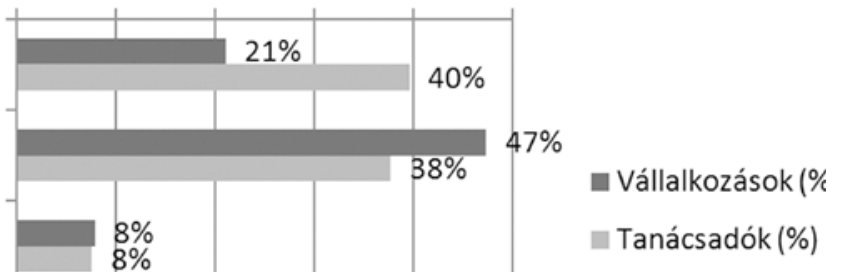

Eyéb

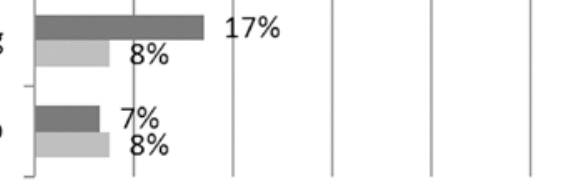

Tanácsadók (\%)

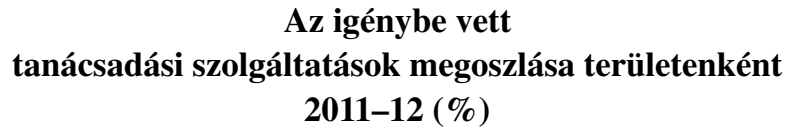

3. ábra

Az igénybe vett 2011-12 (\%)

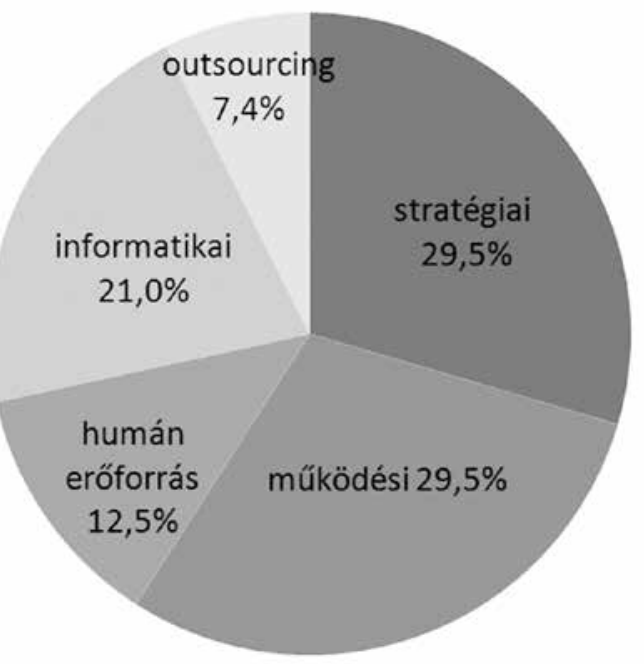

A legnépszerúbb tanácsadási területek a stratégiai és múködési tanácsadás. Felmérésünk szerint az összes 


\section{Az igénybe vett tanácsadási szolgáltatással kapcsolatos tapasztalatok 2001, 2005-06, 2011-12}

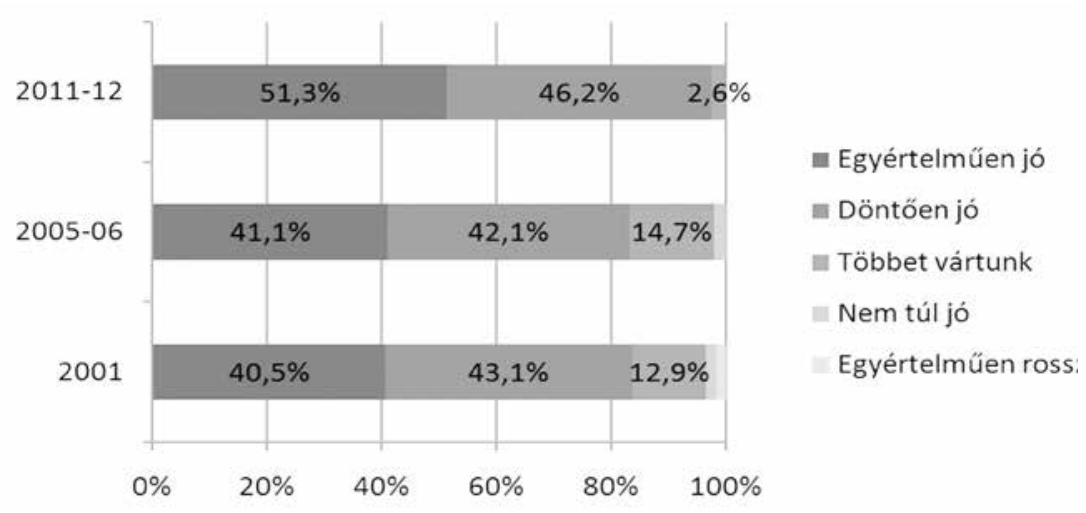

4. ábra másokat is rábeszél, a tanácsadási szakma jó hírét terjeszti. Elenyészô azoknak a száma, akik kiábrándultak tanácsadójukból (2001-ben 3,4\%, 2005-06-ban 2,1\%, 2011-12-ben nem találtunk ilyet), negatív tapasztalatuk alapján 2001-ben mindössze 1,7\% ábrándult ki a teljes tanácsadási szakmából, ớk másokat is lebeszélnek a szolgáltatás igénybevételérôl. 200506-ban, és 2011-12-ben nem találkoztunk olyan ügyféllel, aki egyértelmúen rossz tapasztalatot szerzett volna. A vállalkozók megjelölték, hogy az igénybe vett projektek milyen arányát minôsítik utólag sikeresnek, sikertelennek, illetve az egyértelmúen sikeresnek és sikertelennek sem minôsíthetố projektek arányát (5. ábra).

5. ábra igénybevétel több mint fele (59\%-a) erre a két területre irányul, ezt követi az információtechnológiai tanácsadás $21 \%$ és humáneróforrás-tanácsadás $12,5 \%$-kal. A kérdőívet kitöltő vállalkozók kétharmada $(67,5 \%$ a) stratégiai és múködési tanácsadási szolgáltatást is igénybe vett, majdnem fele $(48,1 \%$-a) informatikai tanácsadót bízott meg, több mint negyede $(28,6 \%$-a) humánerőforrás-gazdálkodási területen vette igénybe tanácsadó szolgáltatását.

A kérdőívekkel nyert adatok feldolgozásához az SPSS 14.0 programcsomagot alkalmaztam. Az elemzés kereszttáblaelemzéssel (függetlenségvizsgálattal), varianciaanalízissel, valamint korrelációelemzéssel történt, a társadalomtudományi kutatásokban szokásos 5\%-os szignifikancia mellett.

\section{Az igénybe vett tanácsadási szolgáltatással kapcsolatos tapasztalatok}

A 4. ábra a 2001-es, 2005-06-os, és a 2011-12-es felmérések alapján mutatja az igénybe vett tanácsadási szolgáltatással kapcsolatos tapasztalatokat.

Majdnem mindegyik megkérdezett ügyfél (201112-ben 97,5\%) elégedett volt tanácsadója teljesítményével, tapasztalatai birtokában most is, bátran hozzá fordulna segítségért, 51,3\% olyannyira elégedett, hogy
Az igénybe vett

tanácsadási szolgáltatás utólagos értékelésének eredménye 2001, 2005-06, 2011-12

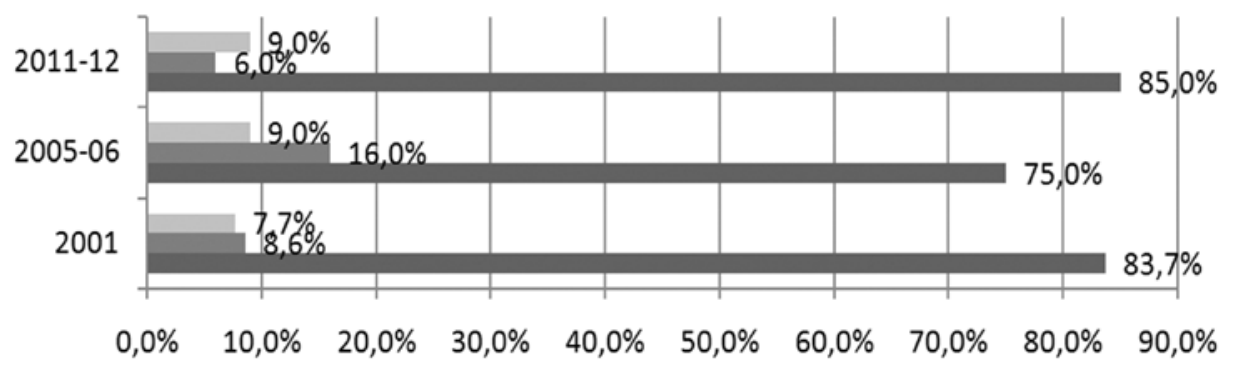

Egyértelműen sikeresnek és sikertelennek sem ítélhető igénybevételek aránya (\%)

- Sikertelen génybevételek aránya (\%)

- Sikeres igénybevételek aránya (\%)

Az eredmény hasonló képet mutat, mint a 4. ábrán közölt adatok, tehát a vállalkozók a projektek eredményessége alapján alkotnak képet a tanácsadóról, a tanácsadási szakmáról. Az utólag sikeresnek ítélt projektek aránya a meghatározó: a vizsgált idôszakban $75 \%$ és $85 \%$ között volt, míg az utólag sikertelennek minősített projektek aránya mindössze $6 \%$ és $16 \%$ közötti.

A tanácsadó és az igénybe vett szolgáltatás megítélését szemlélteti a 6 . ábra a tanácsadók és ügyfeleik megítélése szerint 2011-12-ben.

A szolgáltatást igénybevett ügyfelek 1-tôl 5-ig terjedô skálán értékelték a tanácsadóval való kapcsolatukat, a tanácsadójuk szakmai kompetenciáját, a szolgáltatás ára és a teljesítés színvonala közti kapcsolatot, valamint 
a javaslat megoldásra orientáltságát. (Az 5-ös jelentése teljes mértékben elégedett, 1-es: egyáltalán nem elégedett.) A tanácsadók ügyfeleikkel való kapcsolatukat értékelték az együttmúködés során, a saját szakmai kompetenciájukat, valamint hogy véleményük és az ügyfelek visszajelzései szerint mennyire van arányban a szolgáltatás színvonala az árával, és a javaslatuk mennyire megoldásra orientált.

Az ügyfelek, a felmérés szerint, habár egy kicsit elégedettebbek a tanácsadójukkal (az együttmúködés során az egymás közötti kapcsolattal, valamint a tanácsadójuk szakmai kompetenciájával), mint a kapott szolgáltatással (ár-teljesítés színvonala, és a javaslat megoldásra orientáltsága), alapvetően mindkettőt megfelelőnek ítélték: valamennyi kritériumot az 5 fokozatú Likert-skálán 4,47 felettire értékelték.

A tanácsadók és ügyfeleik véleménye megegyezik, nem mutatható ki szignifikáns különbség (a vizsgált 4 kritériumból 3 esetén): a tanácsadók ügyfeleikhez hasonlóan látják, értékelik szakmai kompetenciájukat, az egymás közti kapcsolatot az együtt-

A tanácsadók és

az igénybe vett szolgáltatás megítélése a tanácsadók és ügyfeleik értékítélete szerint 2011-12

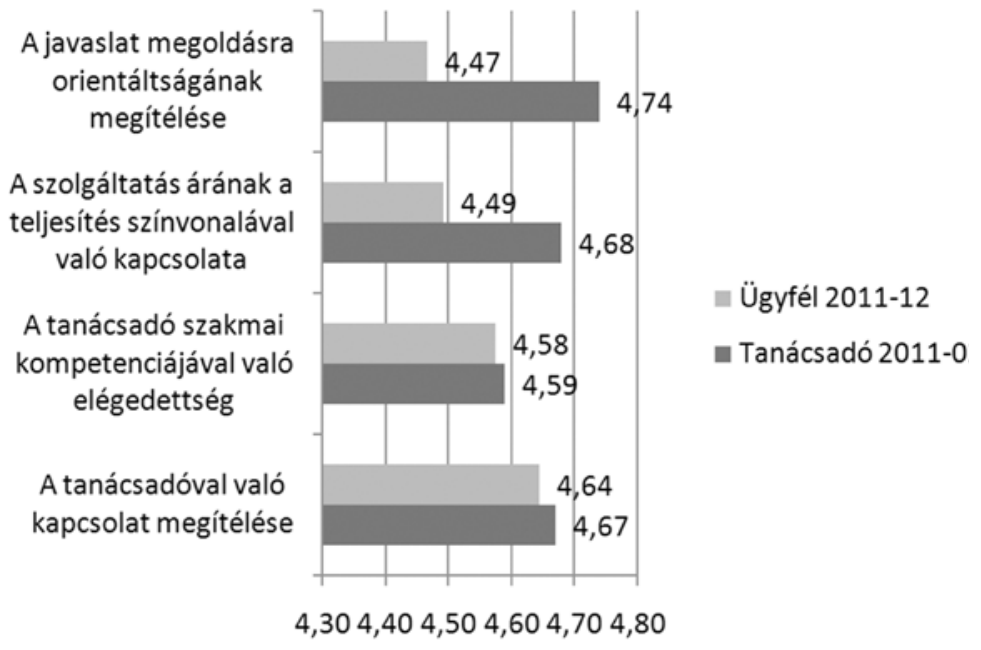

múködés során, valamint az ár és a teljesítmény viszonyát. Habár a felmérés eredménye (6. ábra) szerint a tanácsadók egy kicsit felülértékelték az általuk nyújtott szolgáltatások esetén az ár és a teljesítés színvonala közötti kapcsolatot az ügyfeleik értékítéletéhez képest, de a különbség a szokásos 5\%-os szignifikanciaszinten nem volt szignifikáns $(7,6 \%)$, átlagosan az öt fokozatú Likert-skálán 4,58-ra értékelték. A tanácsadók és ügyfeleik értékítélete között mindössze egynél talál-

7. ábra

\section{az igénybe vett szolgáltatás megítélése az ügyfelek értékítélete szerint 2011-12-ben}

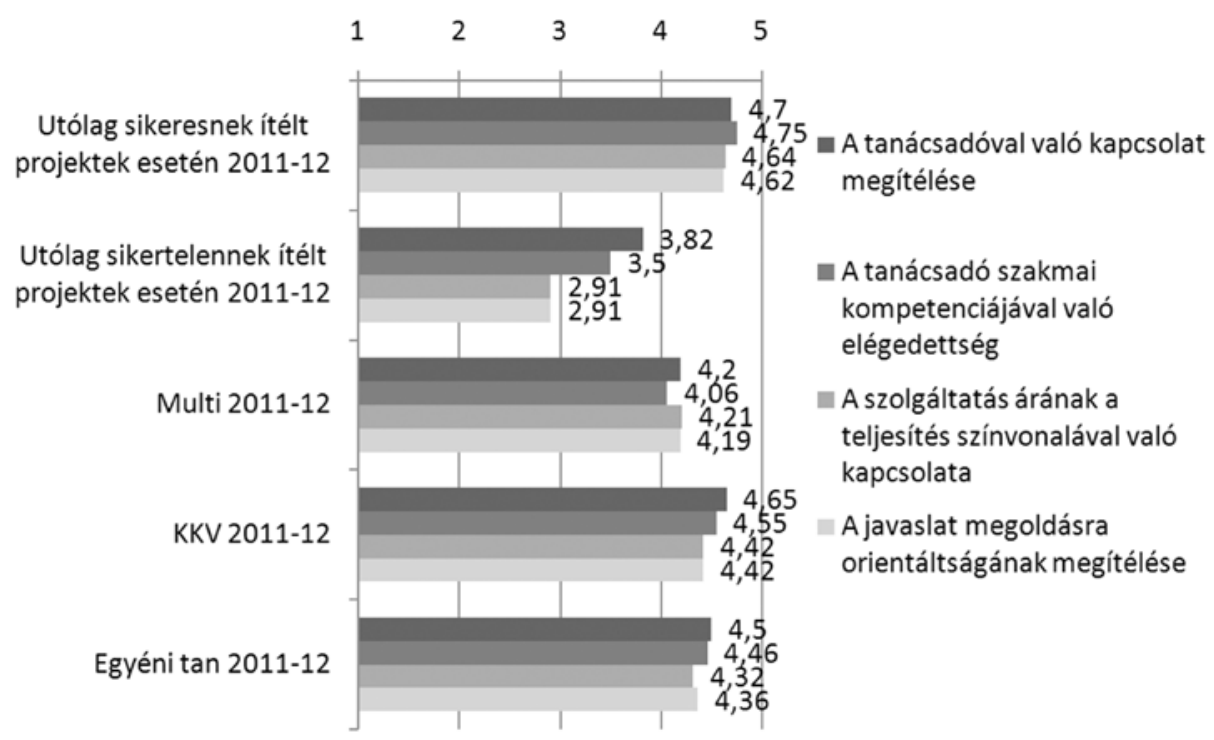

6. ábra ható szignifikáns különbség: a tanácsadók értékítélete szerint a javaslatuk megoldásra orientált (4,74-re értékelték átlagosan), míg ügyfeleik kevésbé tartják a gyakorlatban közvetlenül megvalósíthatónak (átlagosan 4,47re értékelték).

A 7. ábra összefoglalja azokat az észrevételeket, amelyeket a vizsgált ügyfelek a tanácsadóval és a tanácsadási szolgáltatással kapcsolatosan 2011-12-ben tapasztaltak.

A vizsgált vállalkozások utólag sikeresnek minôsített projekt esetén teljes mértékben elégedettek a szolgáltatással és tanácsadójukkal: a kapott javaslatot megoldásra alkalmasnak ítélték, és véleményük szerint megérte az árát. Utólag sikertelennek ítélt projekt esetén közepesen elégedettek tanácsadójukkal, a szolgáltatással nem elégedettek, bár ezeket a javaslatokat sem ítélték teljesen használhatatlannak, teljes pénzkidobásnak. 


\section{8. ábra A 8. ábra a tanácsadási \\ A szolgáltatással kapcsolatos \\ elégedetlenség okai a vizsgált ügyfelek \%-ában, \\ 2011-12-ben \\ szolgáltatással kapcsolatos elégedetlenség okait mutatja a vizsgált ügyfelek tapasztalatai}

$\begin{array}{lllllll}0,0 \% & 2,0 \% & 4,0 \% & 6,0 \% & 8,0 \% & 10,0 \% & 12,0 \%\end{array}$

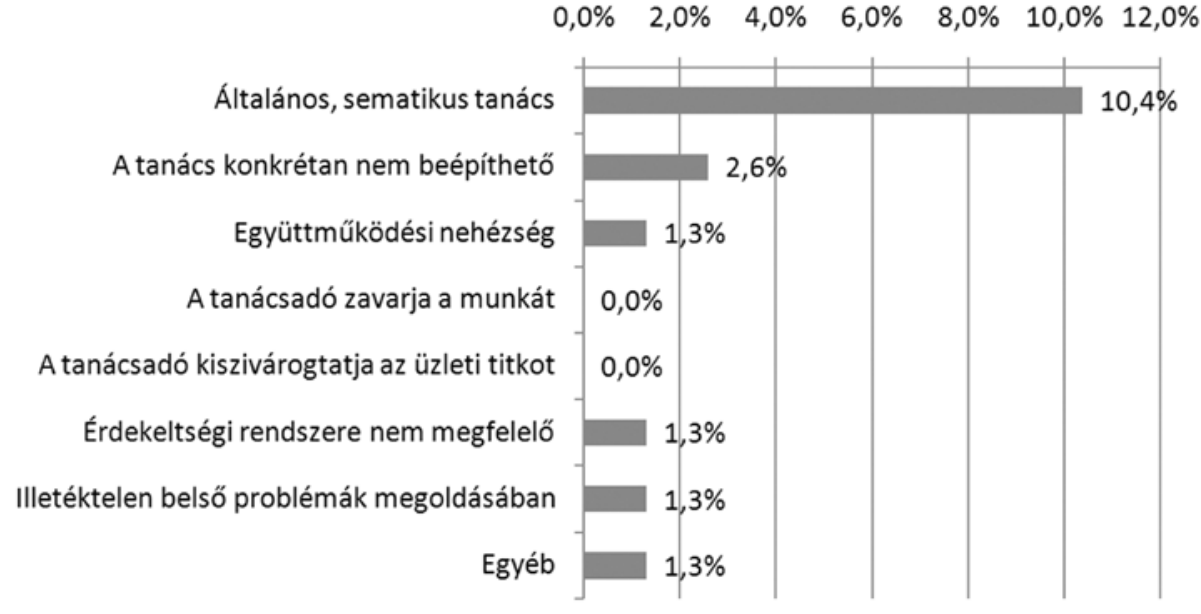
alapján 2011-12-ben.

A vizsgált ügyfelek mindössze $15,6 \%$-a fogalmazott meg - tapasztalatai alapján - tanácsadással kapcsolatos elégedetlenségi okot. A kifogásolt okok legnagyobb része a javaslat megoldásra orientáltságával kapcsolatos: a vizsgált vállakozók10,4\%-a konkrét, egyedi problémákra általános, sematikus tanácsot kapott, 2,6\% a tanácsot nem tudta konkrétan alkalmazni, beépíteni. A többi ok részaránya nem jelentős.
Tanácsadójukból sikertelen projekt esetén sem ábrándultak ki teljesen - kevés kivételtôl eltekintve -, nem keresnek másik tanácsadót. Ennek oka, hogy a legtöbb vizsgált vállalkozás már évek óta kapcsolatban áll tanácsadójával, számos sikeres projektet megvalósítottak közösen, alapvetően elégedettek tanácsadójukkal: egykét eredménytelenebb projekt miatt alapvetően nem változtatják meg véleményüket.

Felmérésünk szerint az ügyfelek kismértékben elégedettebbek a kisebb méretú tanácsadó cégekkel, illetve egyéni tanácsadókkal és szolgáltatásaival, mint a multinacionálisokkal. A rugalmasabb, kisebb méretú tanácsadó vállalkozókkal személyesebb, jobb kapcsolatot tudnak kiépíteni, míg a multinacionális cégek esetén erre sokkal kisebb a lehetőségük.

A vizsgált ügyfelek kismértékben elégedettebbek a kisebb méretú tanácsadó cégek és egyéni tanácsadók kompetenciájával, mint a nagyokéval. Véleményük szerint a kicsik magas színvonalú szolgáltatást nyújtanak az adott területen, és a nagyoknál jobban tudnak alkalmazkodni a speciális helyi igényekhez.

Mivel a vizsgált vállalkozók véleménye szerint a kisebb tanácsadók magas színvonalú, a speciális igényekhez jobban igazodó szolgáltatást nyújtanak az adott területen, a nagyoknál alacsonyabb áron, kedvezőbbnek ítélik meg az ár és teljesítmény közti kapcsolatot, bár nem maradéktalanul elégedettek vele (4,4-re értékelték).

$\mathrm{Az}$ ár-teljesítmény viszonyhoz hasonlóan ítélik meg a javaslat megoldásra orientáltságát. Véleményük szerint a multinacionális tanácsadók javaslatai általánosabbak, míg a kisebb tanácsadóké a gyakorlatban jobban használhatók, de a különbség nem jelentős, öt fokozatú Likert-skálán mindössze 0,2.

\section{Összefoglalás, következtetések}

A Miskolci Egyetem Gazdálkodástani Intézete által 2001-ben, 2005-06-ban és 2011-12-ben végzett kérdőíves felmérések alapján bemutattam, hogy hogyan vélekednek az ügyfelek a tanácsadóikról, mennyire elégedettek az igénybe vett tanácsadási szolgáltatással.

A vizsgált vállalkozások meghatározó hányada, 97,5\%-a elégedett volt tanácsadója teljesítményével, tapasztalatai birtokában most is hozzá fordulna segítségért. A legnépszerúbb a stratégiai és múködési tanácsadás, az összes igénybevétel több, mint fele erre irányul, a kérdőívet kitöltő vállalkozók kétharmada mindkét területen igénybe vette a szolgáltatást. Az igénybe vett projektek meghatározó hányadával elégedettek voltak, mintegy 85\%-át utólag sikeresnek minősítették a megkérdezett vállalkozók.

Felmérésünk szerint a vállalkozások kismértékben elégedettebbek voltak a kisebb méretű tanácsadó cégekkel, illetve egyéni tanácsadókkal és szolgáltatásaival, mint a multinacionálisokkal: közvetlenebb, személyesebb kapcsolatot tudtak kiépíteni, javaslatuk a gyakorlatban jobban használható volt, jobban tudtak alkalmazkodni a speciális helyi igényekhez, a szolgáltatás ára jobban fedte a teljesítményt.

2011-12-ben a megkérdett vállalkozók mindössze 15,6\%-a fogalmazott meg - tapasztalatai alapján - tanácsadással kapcsolatos elégedetlenségi okot. A kifogásolt okok legnagyobb része a javaslat megoldásra orientáltságával kapcsolatos. Konkrétabb, könnyebben beépíthető, megoldásra orientáltabb javaslatokkal jobban meg tudnának felelni az ügyfelek igényeinek. 
A megbízást nem szabad bizonytalan és vegyes érzelmekkel befejezni. Az árak és a leszállított anyagok, megoldások minőségének, hasznosságának, hatásának kérdésein túl, fontos a projektek valódi (komplex) szakmai értékelésének elvégzése is, melynek szerves része a tanácsadói magatartás, valamint a tanácsadó és az ügyfél együttmúködésnek a vizsgálata. Ideális esetben mindkét félnek elégedettnek kell lennie a megbízás alatt fennálló kapcsolattal. Jó, ha az ügyfél pozitívan értékeli a konzultáns munkáját, akivel legközelebb is szívesen múködik együtt. A tanácsadónak éreznie kell, hogy munkáját megbecsülik és elismerik, valamint azt, hogy az adott ügyféllel végzett közös munka ösztönzôleg hat saját tevékenységére is.

A jó tanácsadó tanul megbízásaiból, ügyfelétől, hibáiból: tapasztalatot, gyakorlatot szerez, a kompetenciája növekszik, a következô megbízásában már ezt az új ismeretet is felhasználja. A tanácsadó fejlódéséhez nélkülözhetetlen a visszajelzés, az értékelés. A jó tanácsadó szigorú szempontok szerint értékeli saját tevékenységét is: hiszen így tanulhat hibáiból, így növelheti kompetenciáját. A visszacsatolás és értékelés a tanácsadó továbbfejlődésének alapja: nélkülözhetetlen a tanácsadó módszereinek továbbfejlesztésében, a tanácsadás hatékonyságának növelésében - új módszerek kifejlesztésének, ezáltal a versenyképesség megőrzésének nélkülözhetetlen feltétele.

\section{Lábjegyzet}

${ }^{1}$ A kutatómunka a Miskolci Egyetem stratégiai kutatási területén múködő Mechatronikai és Logisztikai Kiválósági Központ keretében valósult meg.

\section{Felhasznált irodalom}

Bódis A. (2008): Az osztrák választási botrány magyar szálai http://hetivalasz.hu/reflektor/tobb-szdsz-tobbstrabag-20119/ (letöltve: 2010. augusztus)
FEACO (2000-2004): Survey of the Management Consultancy market 2000, 2001, 2002, 2003, 2004 http:// www.feaco.org/en/index-action-marketInformation. html (letöltve: 2013. szeptember)

FEACO (2005-2012): Survey of the Management Consultancy market 2005-06, 2007-08, 2008-09, 2010-11, 2011-12) http://www.feaco.org/en/indexaction-marketInformation.html (letöltve: 2013. szept.)

Hoványi G. (1997): Menedzsment-tanácsadás. Pécs: JPTE

$K u b r, M$. (ed.) (2002): Management consulting: a guide to the profession. Geneva: ILO

Niedereicholz, Ch. (2008): Unternehmensberatung. Brand1. München: Oldenbourg Verlag

Pelczné - Szadai (2003a): Az üzleti tanácsadási tevékenység Borsod-Abaúj-Zemplén megyében 1. rész. Vezetéstudomány, 6. szám

Pelczné - Szadai (2003b): Borsod-Abaúj-Zemplén megyei székhelyú tanácsadó cégek jellemzôi, fejlődési lehetôségeik 2. rész. Vezetéstudomány, 7-8. szám

Pelczné - Szadai (2004): A tanácsadói projektek megítélése 1. rész. Vezetéstudomány, 6. szám

Pelczné Gáll - Szadai (2006): Üzleti tanácsadás alapjai. Miskolc: Bíbor Kiadó

Pénzes D. (2009): BKV-botrány bizonyító dokumentumokkal. 2009. március 9 http://www.hirextra.hu/2009/03/03/ bkv-botrany-bizonyito-dokumentumokkal/ (letöltve: 2010. augusztus)

Philips, J. (2000): Consultants Scorecard. London: McGrawHill

Poór J. (2010): Menedzsment tanácsadási kézikönyv. Budapest: Akadémiai Kiadó

Szadai Á. (2006): Borsod-Abaúj-Zemplén megyei üzleti tanácsadási piac változása 2001 és 2005 között (VI. Regionális Tanácsadási Konferencia Miskolc, október 12.

Tokár-Szadai Á. (2012): Az üzleti tanácsadási rendszer modellje. Vezetéstudomány, XLIII. évf., különszám

Tokár-Szadai Á. (2013a): Tanácsadói szerepek, kompetenciák. Vezetéstudomány XLIV. évfolyam, 3. szám

Tokár-Szadai Á. (2013 b): Kulcskompetenciák a tanácsadásban. Gép, 1. szám 